\section{from EDITORS}

$\nabla$ 昨年 9 月に関東から東海地方に引っ越しまし た. グローバル化の時代といってもやはり地方色 はあり，いろいろな違いを楽しんでいます。最近 一番気に入ったのは紅葉の美しさです，気候の違 いなのか, 土壤の違いなのか？ 単に田舎に引っ 越したというだけ…ですかね.

マ「子どもに教えたい通信のしくみ」を読んでい て, 改めて自分たちの使っている便利な機械の原 理を知らないことに気が付きました。これからの 子どもたちは，携帯もETCも Suica も空気のよ うに使うのでしょう。どうして動いているのか？ という疑問を大人が意識的にぶつけてやる必要が あるのかもしれません，好奇心を刺激して理系を 增やしていきたいですね.

『秋葉原以外にも，訪れてみたい場所は多くある. 刈谷の無線通信所跡地など珍しいアンテナがかか わる各所，実物が残されている博物館など、また， 実験室に残された過去の遺物も面白い. 先達の残 された実物から学ぶことは多い.

マ 今年度，念願の音楽 CD を作りました。 2000 年に研専の幹事を仰せつかってから幹事補佐の $\mathrm{K}$ さんと研究会や編集委員会 (の夜) があるたび に練習をしてきた曲を収録しました。たった 3 曲 $(+\alpha)$ ですが，満足のいく出来に仕上がったと 思っています，偶然にも今年度，通信ソサイエ ティマガジン B-plus の CD-ROM が発売されまし た.どちらも逸品です！私の CD は非売品です が, B-plus の CD-ROM は内容満載でお值打ちで すので，皆様，どうぞなくならないうちに扮求め 下さい.

(N.K.)

『編集委員としての初めての仕事として, 開発物 語を担当させて頂きました，今回は，「無線 LAN の開発物語」でしたが，今回の開発物語には，世 の中に広く利用されるシステムを開発するための ヒントが隠れているように思いました。（K.H.）

$\nabla$ B-plus 創刊以来，毎年 3 月発行の春号は， フ レッシュマン特集として，主に若手読者の方への 誌面をお届けしてきておりますが，今回お届けし ました名誉員との対談特集は，いかがだったで しょうか. 一回り二回りどころか，三回りも世代 が違いながらも，世代を超えて共通する話題や悩 みなどもあり，興味深い内容になりました。おじ いちゃん世代から孫世代への熱い思いを，是非味 わってみて下さい.

(K.Y.)

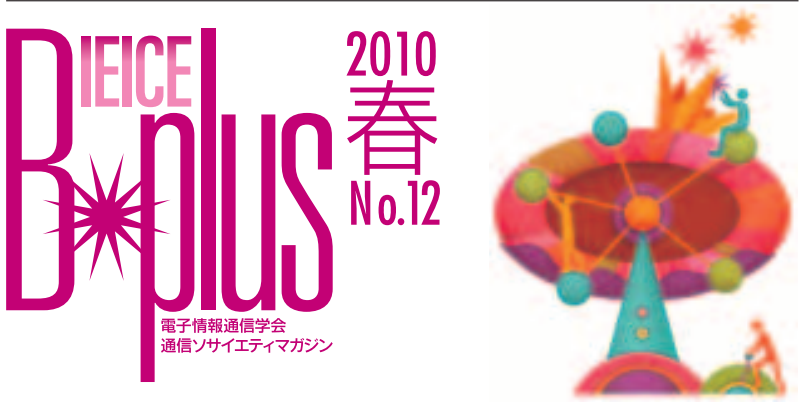

2010 年 2 月 25 日印刷 2010 年 3 月 1 日発行 Editorial Board

$\begin{array}{cllll}\text { 編集委員長 } & \text { 山尾 泰 } & & & \\ \text { 編集副委員長 } & \text { 上林真司 } & \text { 菊間信良 } & \text { 山岡克式 } & \\ \text { 編 集 委 員 } & \text { 阿久津明人 } & \text { 朝香卓也 } & \text { 安部田貞行 } & \text { 稲葉敬之 } \\ & \text { 井原雅行 } & \text { 大槻知明 } & \text { 大橋正良 } & \text { 小瀬木滋 } \\ & \text { 小野文枝 } & \text { 笠原正治 } & \text { 神尾享秀 } & \text { 佐波孝彦 } \\ & \text { 清水 聡 } & \text { 庄木裕樹 } & \text { 関屋大雄 } & \text { 平 明徳 } \\ & \text { 高橋応明 } & \text { 田島公博 } & \text { 辻 宏之 } & \text { 戸出英樹 } \\ & \text { 中村 元 } & \text { 濱辺孝二郎 } & \text { 広川郎 } & \text { 馬杉正男 } \\ & \text { 松田崇弘 } & \text { 山崎克之 } & & \end{array}$

2010 年夏号（第 13 号）２010年6月1日発行

私の技術者歴飯田尚志

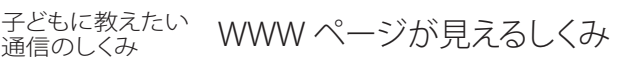

小特集多様化する情報通信環境を提供する

開発物語 MPEG 開発物語

本誌の愛称は「B-plus」, 正式名称は「通信ソサイエティマガジン」, 「IEICE Communications Society Magazine」です,

本誌掲載論文を文献引用する際は, 邦文略称「信学通誌」, 英文略称 「IEICE Commun. Mag.」を用いて下さい.

\section{【通信ソサイエティマガジン B-plus へのお問い合わせ】}

口御意見，御要望，入手など : b-plus@ieice.org $\square$ ロームページ：

http://www.ieice.org/cs/jpn/pub/magazine/

口複写される方へ：本会は下記協会に複写に関する権利委 託をしていますので，本誌に掲載された著作物を複写し たい方は，同協会より許諾を受けて複写して下さい。た だし，（社）日本複写権センター（同協会より権利を再委 託）と包括複写許諾契約を締結されている企業の社員に よる社内利用目的の複写はその必要はありません（社外 頒布用の複写は許諾が必要です)

権利委託先：(社) 学術著作権協会

170-0052 東京都港区赤坂 9-6-41 乃木坂ビル Tel : 03-3475-5618 Fax : 03-3475-5619 E-mail : info@jaacc.jp

なお，著作物の転載・翻訳のような複写以外の許諾は，直 接本会へ御連絡下さい.

著作権利用許諾については

http://www.ieice.org/jpn/service/tensaitokkyo/

発行者 / 木暮賢司

発行所 / (社) 電子情報通信学会 通信ソサイエティ

105-0011 東京都港区芝公園 3-5-8 機械振興会館

TEL : 03-3433-6691 (代表) 振替：00120-0-35300

制 作/ (株) エヌ・ピー・エス

111-0051 東京都台東区蔵前 2-5-4 北條ビル

(C) Copyright 2010 IEICE. All rights reserved. 